\title{
Estimasi Kejadian Covid-19 Secara Real Time menggunakan R Programming
}

\author{
Adnan Sauddin \\ Universitas Islam Negeri Alauddin Makassar,adnan.sauddin@uin-alauddin.ac.id
}

Try Azisah Nurman

Universitas Islam Negeri Alauddin Makassar,wahidah.alwi@uin-alauddin.ac.id

Khalilah Nur Fadilah

Universitas Islam Negeri Alauddin Makassar

\begin{abstract}
ABSTRAK, Pada artikel ini menguraikan Langkahlangkah estimasi kejadian covid-19 di Indonesia khusus wilayan Sulawesi selatan secara real time menggunakan Bahasa R.
\end{abstract}

\begin{tabular}{l} 
Kata Kunci: $R$ programming, $\begin{array}{l}\text { Covid-19, } \\
\text { distribusi poisson, estimasi } \\
\text { likelihood }\end{array}$ \\
\hline
\end{tabular}

\section{PENDAHULUAN}

Pada artikel ini penulis akan menguraikan penggunaan program $\mathrm{R}$ tahap demi tahap dalam melakukan estimasi terhadap kejadin Covid-19 secara real time. Bahwa pandemic covid-19 merupakan kejadian luar biasa yang meliputi seluruh dunia. Tidak satupun negara kecuali terpapar virus ini. peningkatan kejadian terpapar covid-19 dari hari ke hari terus yang terus meningkat membuat setiap negara berusaha secara maksimal untuk menekan kejadian terpapar.

Peningkatan kejadian terpapar virus corona berbeda pada setiap negara, hal tersebut bergantung pada pendekaatan penanganan yang dilakukan oleh setia otoritas negara. Jika kita melihat pada konsep islam dalam penanganan suatu wabah pandemic, bahwa disebut dalam salah satu hadits Rasulullah Sholallahu 'alai wasallam, secara makna-ketika suatu negeri menyebar wabah, maka orang-orang yang berada diluar daerah tersebut dilarang untuk masuk, searah dengan hal tersebut, orang-orang yang berada di dalam suatu daerah tersebut (daerah pandemic) dilarang untuk keluar dari daerah tersebut. Beberapa negara ada yang menerapkan konsep tersebut, dalam cukup berhasil dalam menekan tingkat penyebaran dari virus tersebut.

Ketika wabah tersebut telah menyebar dalam suatu negeri, hal yang mungkin bisa dilakukan adalah menekan jumlah penyebaran dari waktu ke waktu. Memahami factor-faktor penyebab terus bertambahnya kejadian terpapar virus covid-19 merupakan hal tindakan yang harus dilakukan agar Tindakan prefentiv dapat segera dilakukan. Salah satu factor yang dapat mempengaruhi Jumlah kejadian covid-19 sangat berkaitan terkait dengan teknik pengukuran atau alat ukur yang digunakan, tingkat validitas alat ukur akan menentukan validnya data yang berkaitan dengan jumlah terpapar. Untuk dapat mengambil Tindakan preventif, mengetahui kemungkinan pertambahan jumlah kejadian terpapar dengan kluster atau segmentasi berdasarkan daerah akan memudah bagi pengambil kebijakan untuk menerapakan kebijakan protocol Kesehatan yang dapat membantu penanganan perluasan dan/atau penurunan jumlah kejadian terpapar.

estimasi peluang peningkatan dan/atau penurunan jumlah kejadian, secara statistic dalam dilakukan dengan menggunakan beberapa model berdasarkan pada distribusi kejadian. Distribusi poisson untuk mendeteksi jumlah kejadian terpapar - model kedatangan - dengan estimasi likelihood. Memanfaat informasi prior akan meningkatkan tingkat keakuratan hasil estimasi - aturan bayes.

\section{TINJAUAN PUSTAKA}

\section{Jumlah orang menjadi terpapar per orang yang terinfeksi berdasarkan waktu $t$}

\section{Model Kedatangan}

Model keadatangan proses terpapar mengikuti pola distribusi poisson. Misalkan $\lambda$ merupakan rata kejadian terpapar perhari dan 
peluang yang mungkin $k$ kasus baru perhari, berdistribusi poisson dengan persamaan

$$
P(k \mid \lambda)=\frac{\lambda^{k} e^{-\lambda}}{k !}
$$

Dapat dikonstruksi suatu distribusi peluang dari kasus baru untuk suatu $\lambda$.

\section{Estimasi Likehood Distribusi Poisson}

Pemodelan proses kedatangan distribusi poisson memungkinkan bagi kita untuk melakukan prediksi terhadap distribusi kasus kejadian baru dalam suatu hari sebagai suatu fungsi rata-rata kedatangan $(\lambda)$. Namun demikian, pada data real, kita hanya dapat mengamati jumlah kedatangan. Untuk mendapatkan keadaan yang dimaksud, maka kita perlu melakukan estimasi terhadap kejadian baru yang akan datang, salah satu metode yang popular adalah likelihood.

Distribusi dari $\lambda$ untuk sembarang $k$ disebut fungsi likelihood, yakni:

$$
L(\lambda \mid k)=\frac{\lambda^{k} e^{-\lambda}}{k !}
$$

\section{Menghubungkan $\lambda$ dan $R_{t}$} matematis

Hubungan antara $\lambda$ dan $R_{t}$ secara

$$
\lambda=k_{t-1} \gamma^{\left(R_{t}-1\right)}
$$

Gunakana persamaan terakhir dan subtitusi ke persamaan sebelumnya

Hasilnya

$$
L(\lambda \mid k)=\frac{\lambda^{k} e^{-\lambda}}{k !}
$$

$$
L\left(R_{t} \mid k\right)=\frac{\lambda^{k} e^{-\lambda}}{k !}
$$

\section{Estimasi $\boldsymbol{R}_{t}$}

Untuk mengestimasi kejadian secara time series kita dapat menggunakan aturan bayes,

$$
\begin{gathered}
L(\lambda \mid k)=\frac{\lambda^{k} e^{-\lambda}}{k !} \\
L\left(R_{t} \mid k_{t}\right)=\frac{P\left(R_{t}\right) L\left(k_{t} \mid R_{t}\right.}{P\left(k_{t}\right)}
\end{gathered}
$$

Jika menggunakan $L\left(R_{t} \mid k_{t}\right)$ sebagai prior dari $P\left(R_{t}\right)$ untuk suatu periode tertentu, maka persamaan sebelumnya dapat dituliskan

$$
L\left(R_{t} \mid k_{t}\right) \propto P\left(R_{t-1} \mid k_{t-1}\right) \cdot L\left(\frac{P\left(R_{t}\right) L\left(k_{t} \mid R_{t}\right)}{P\left(k_{t} \mid R_{t}\right)}\right.
$$

diperoleh

Iterasi silang semua periode, $t=0$,

$$
L\left(R_{t} \mid k_{t}\right) \propto P\left(R_{0}\right) . \prod_{t=0}^{T} L\left(k_{t} \mid R_{t}\right)
$$

Dengan prior yang seragam, $P\left(R_{0}\right)$, direduksi ke

$$
P\left(R_{t} \mid k_{t}\right) \propto \prod_{t=0}^{T} L\left(k_{t} \mid R_{t}\right)
$$

\section{Paket $R$ yang digunaka}

Pada program $r$, terdapat banyak paket yang telah dikembangkan oleh banyak pengembang. Dalam menganalisis kejadian Covid-19 secara real time, berikut paket-paket yang digunakan:

1. tidyverse

2. ggplot2

3. HDinterval

4. smooter

serta beberapa paket lain yang dapat dilihat pada script Bahasa r pada bagian hasil.

\section{HASIL}

\section{Pengaturan Tampilan Ourput R}

\section{\# Load packages}

library (tidyverse)

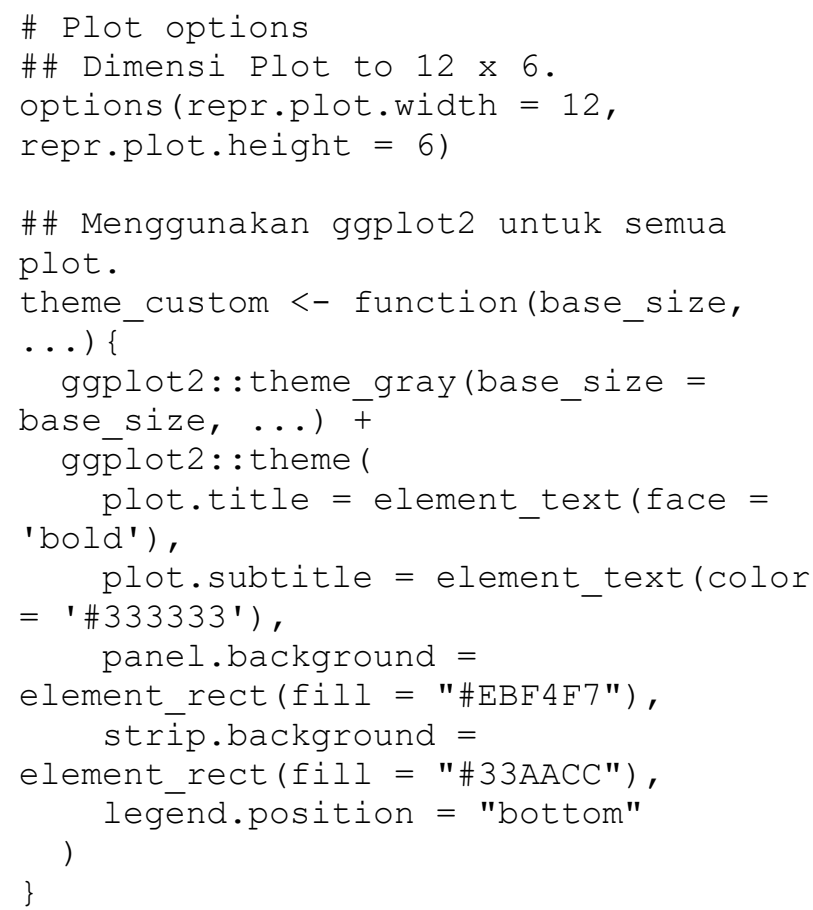




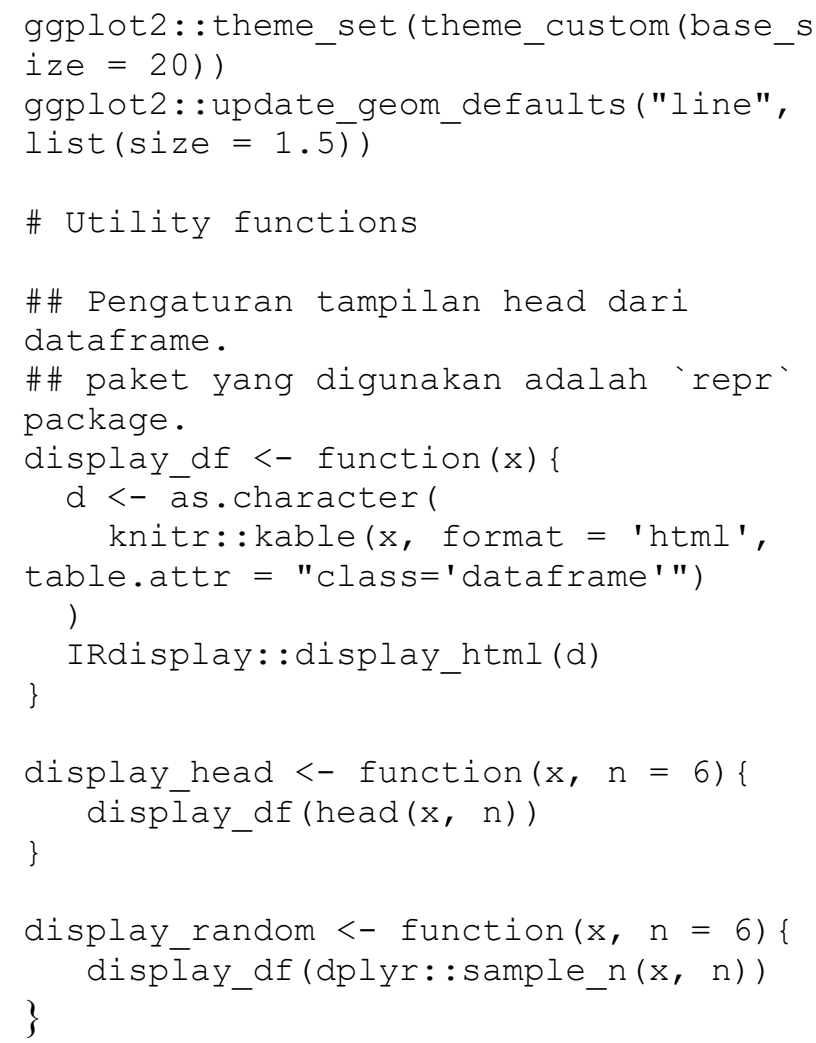

Simulasi "Kedatangan" Terpapar Baru per Hari

\# Jumlah Kasus Baru dalam se-hari $\mathrm{k}=0: 69$

\# Rata-Rata "Kedatangan terpapar baru per hari

lambda $=c(10,20,30,40)$

poisson densities = crossing(lambda $=$ lambda, $\mathrm{k}=\mathrm{k}$ ) $\frac{\circ}{0}>\frac{\circ}{0}$ mutate $(\mathrm{p}=\operatorname{dpois}(\mathrm{k}, \mathrm{lambda}))$

display_head (poisson_densities)

\begin{tabular}{c|c|c}
\hline lambda & $\mathbf{k}$ & $\mathbf{p}$ \\
\hline 10 & 0 & 0.0000454 \\
10 & 1 & 0.0004540 \\
10 & 2 & 0.0022700 \\
10 & 3 & 0.0075667 \\
10 & 4 & 0.0189166 \\
10 & 5 & 0.0378333 \\
\hline
\end{tabular}

\section{Grafik Distribusi Poisson}

poisson_densities $\frac{\circ}{0}$

\# Konver lambda ke fakto sehingga setiap baris berupa menghasil warna yang berbeda (sebagai diskrit) mutate (lambda $=$ factor (lambda) $) \div$ ggplot (aes $(\mathrm{x}=\mathrm{k}, \mathrm{y}=\mathrm{p}$, color $=$ lambda)) + geom_line() + labs ( title = expression(paste("Probability of $k$ new cases $P(k \mid "$, lambda, ")")),

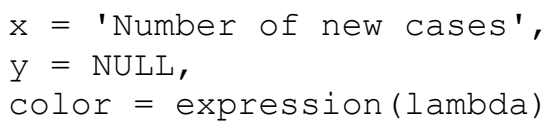

\section{Hasilnya}

Probability of $k$ new cases $P(k \mid \lambda)$

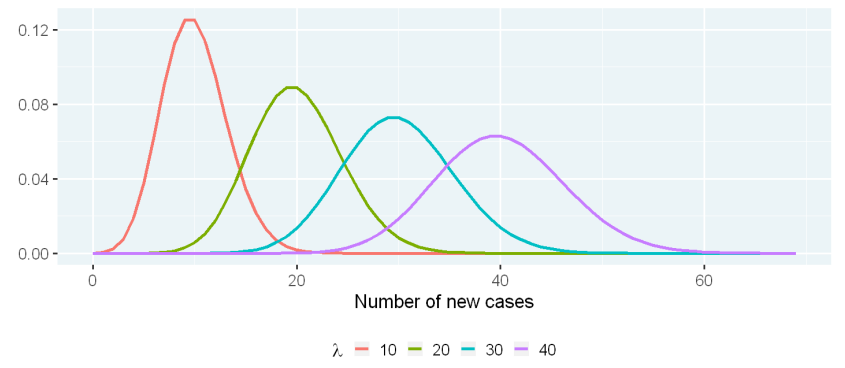

\# Jumlah Kasus Baru Teramati per Hari

$\mathrm{k}=20$

\# Rata-rata Kedatangan terpapar baru per hari

lambdas $=\operatorname{seq}(1,45$, length $=90)$

\# Menghitung likelihood and gambar

Likelihood

tibble(lambda $=$ lambdas, $\mathrm{p}=\operatorname{dpois}(\mathrm{k}$, lambdas)) 응

ggplot (aes $(\mathrm{x}=$ lambda, $\mathrm{y}=\mathrm{p}))+$ geom_line $($ color $=$ 'black' $)+$ labs $\overline{1}$

title = expression (paste("Poisson

Likelihood L(", lambda, " | k"[t], ") ") ),

$\mathrm{x}=$ expression (lambda), $\mathrm{y}=$ NULL

)

\section{Hasilnya}

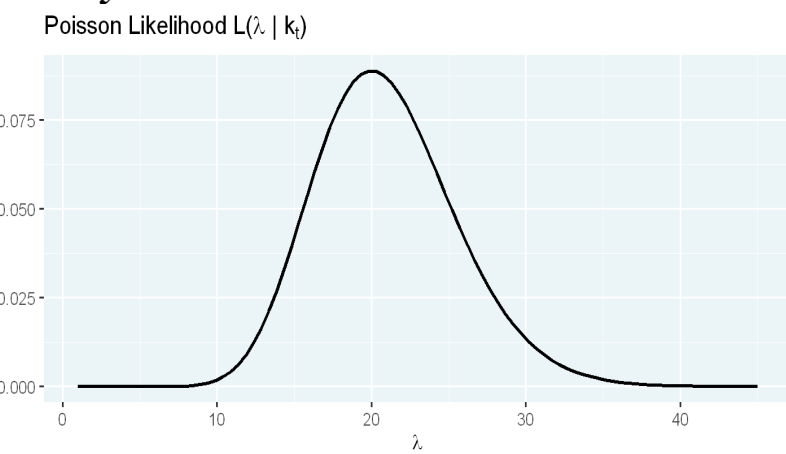

Nilai Peluang untuk rentang $\boldsymbol{R}_{t}$

\# r_t_range is a vector of possible values for $R$ t

$$
\begin{aligned}
& \mathrm{R} \mathrm{T} \text { MAX }=12 \\
& r \text { t range }=\operatorname{seq}(0, \mathrm{R} T \mathrm{MAX} \text {, }
\end{aligned}
$$

length $=\bar{R}$ _T_MAX $\left.{ }_{-} 100+1\right)$

\# Gamma is 1/serial interval

GAMMA $=1 / 4$

Jurnal Matematika dan Statistika serta Aplikasinya Vol. 8 No. 1 Ed. Jan - Juni 2020 
\# Kasus Baru Perhari

$\mathrm{k}=\mathrm{c}(20,40,55,90)$

likelihoods <- tibble (day $=$

seq_along $(\mathrm{k})-1, \mathrm{k}=\mathrm{k}) \frac{\circ}{\mathrm{O}}>\frac{\mathrm{o}}{\mathrm{O}}$

\# Menghitung vector likelihoods mutate (

$r_{-} t=$ list (r_t_range),

$1 \overline{a m b d a}=\operatorname{map}(1 \overline{a g}(\mathrm{k}, 1), \sim \mathrm{x}$

* $\exp ($ GAMMA * (r_t_range - 1))), likelihood_r ${ }_{-}{ }^{t}=\operatorname{map} 2(\mathrm{k}$,

lambda, $\sim \operatorname{dpois} \overline{(. \bar{x}}$

.y) / sum (dpois $(. x, . y)))$

) $\%>\frac{\circ}{0}$

\# Mengabaikan Hari ke-0

filter(day > 0) \% $>$ \%

\# Unnest the data to flatten it. select (-lambda) 응 unnest (c (r_t,

likelihood_r_t) $)^{-}$ display_random (likelihoods)

\begin{tabular}{c|c|c|c}
\hline day & $\mathbf{k}$ & $\mathbf{r} \_t$ & likelihood_r_t \\
\hline 1 & 40 & 10.55 & 0 \\
3 & 90 & 7.73 & 0 \\
2 & 55 & 7.35 & 0 \\
2 & 55 & 1.27 & 0.0014977 \\
1 & 40 & 1.37 & 0.0000162 \\
3 & 90 & 7.66 & 0 \\
\hline
\end{tabular}

likelihoods 응

ggplot (aes $\left(x=r_{-}, y\right.$

$=$ likelihood_r_t, $\operatorname{col} \overline{o r}=$

factor (k)) ) +

geom_line () +

labsi

title =

expression (paste ("Likelihood of R"[t], "given k")), subtitle $=$

expression (paste ("L (R" [t], "|k)")), $\mathrm{x}=$ expression ("R" $[t])$, $\mathrm{y}=$ NULL, $\operatorname{color}=\mathrm{I}^{\prime}$ )
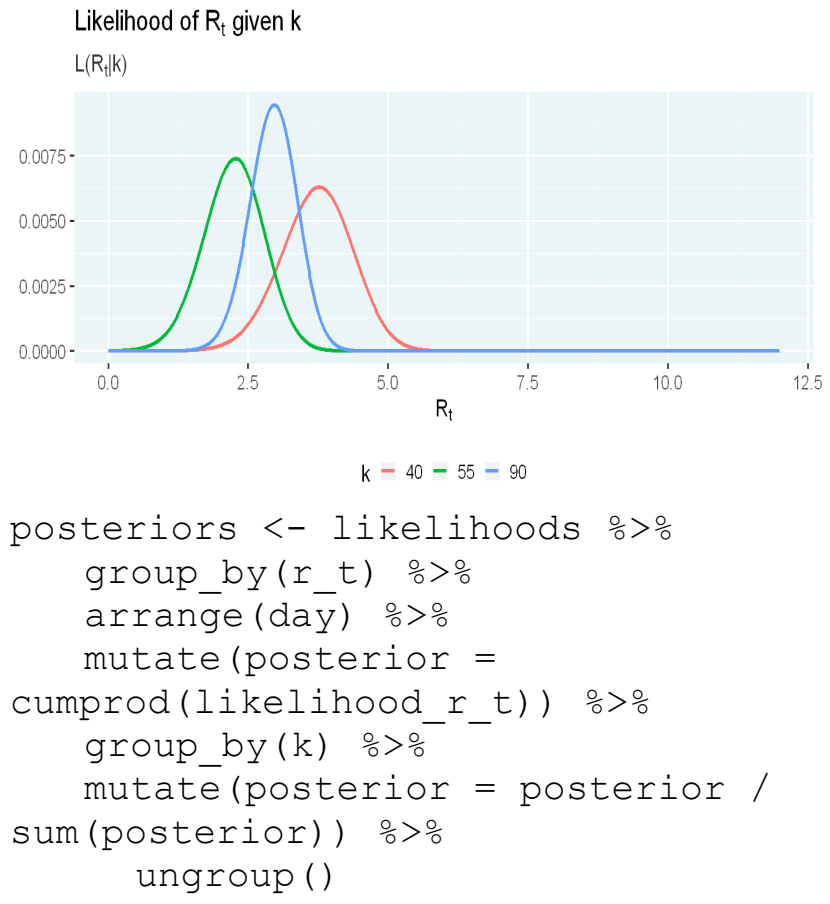

\begin{tabular}{c|c|c|c|c}
\hline day & k & r_t & likelihood_r_t & posterior \\
\hline 2 & 55 & 1.91 & 0.0059229 & 0.0009075 \\
3 & 90 & 4.21 & 0.0000771 & 0.0000002 \\
1 & 40 & 4.21 & 0.0049115 & 0.0049115 \\
2 & 55 & 2.04 & 0.0067356 & 0.0016521 \\
2 & 55 & 8.59 & 0.0000000 & 0.0000000 \\
2 & 55 & 8.09 & 0.0000000 & 0.0000000 \\
\hline
\end{tabular}

posteriors $\%>$

ggplot (aes ( $x=r_{-}, \quad y=$ posterior,

color $=$ factor $(\mathrm{d} \overline{\mathrm{a}} \mathrm{y})))+$ geom_line () + labs $\overline{(}$

Posterior probability of $R_{t}$ given $k$

$P\left(R_{t} \mid k\right)$

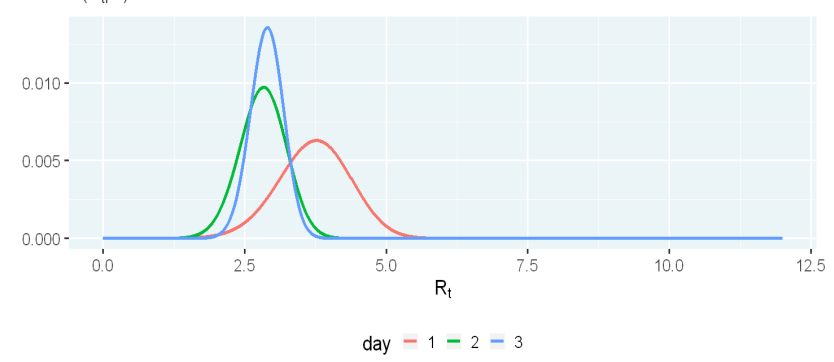

Install and load HDInterval package library (HDInterval) 


\section{Menghitung Nilai $R_{t}$ Nilai dengan Peluang}

\section{Tinggi}

\# menghitung nilai $R_{t}$ yang paling

mungkin dan highest-density interval

estimates <- posteriors $\%>\frac{\circ}{0}$

group by (day) \%>

summarize(

$r$ t_simulated $=$

list (sample (r_t_range, 10000, replace

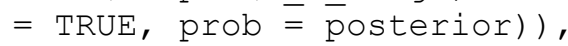

$r$ t_most_likely $=$

r_t_range [which.max (posterior) ]) 응 mutate ( $r_{-} t_{-} l o=$

map_dbl(r_t_simulated, $\left.{ }^{\sim} \sim \operatorname{hdi}(. x)[1]\right)$, r_t_hi =

map_dbl(r_t_simulated, hdi(.x)[2]) ) $\frac{\circ}{\circ}>\circ$

select (-r_t_simulated)

display head (estimates)

\begin{tabular}{c|c|c|c}
\hline day & r_t_most_likely & r_t_lo & r_t_hi \\
\hline 1 & 3.77 & 2.48 & 4.96 \\
2 & 2.84 & 2.02 & 3.61 \\
3 & 2.90 & 2.33 & 3.49 \\
\hline
\end{tabular}

\section{Grafik Interval}

estimates 응

ggplot (aes $(\mathrm{x}=$ day, $\mathrm{y}=$

r_t_most_likely)) + gèom_point (color = "\#ffc844",

size $=5$ ) +

geom line $($ color $=$ 'black') + geom_ribbon (aes (ymin $=r$ t_lo,

$\operatorname{ymax}=r t \bar{h} i)$, fill = "\#ffc844",

alpha $=\overline{0} \cdot \overline{3})+$

labs ( title =

expression (paste('R'[t], ' by day')), subtitle = "The band represents the highest density interval",

$$
\mathrm{x}=\text { 'Day', } \mathrm{y}=\text { NULL) }
$$

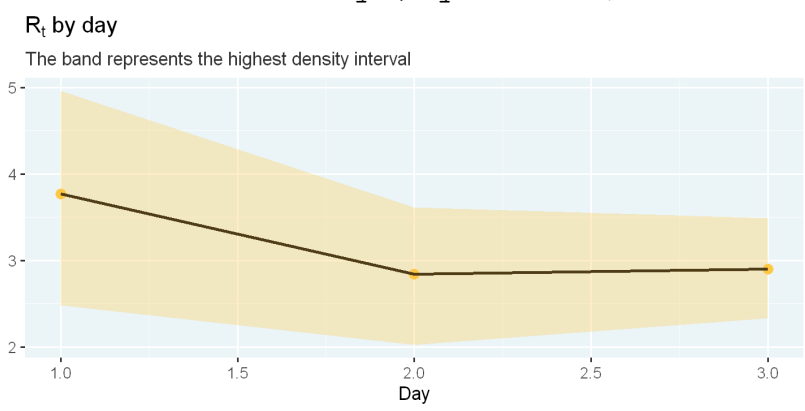

\section{Kasus Covid-19 Indonesia}

\section{Upload Data Covid-19 Indonesia}

covid_cases <-

readr: :read_csv("d:/Statistik_Harian_p

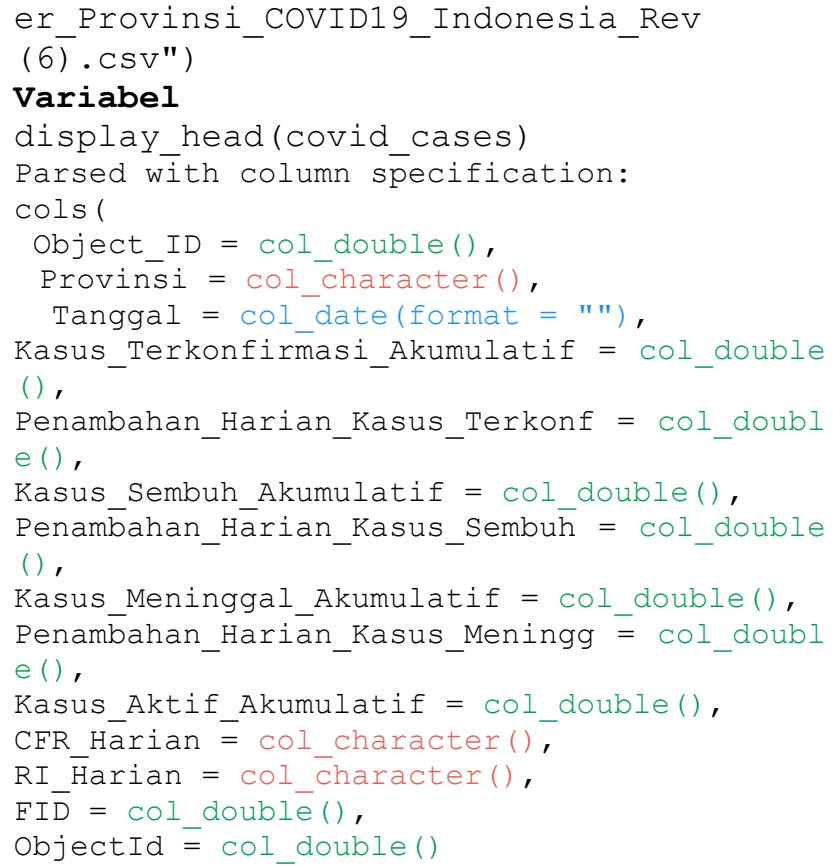

\section{Menampilkan Data Harian Terkonfirmasi dan Pemulusan}

\# Install the smoother packagelibrary (smoother)

\# Menampilkan kasus harian terkonfirmasi dan pemulusannya smooth_new cases <- function(cases) \{ casés $\frac{\circ}{0}>$ arrange (Tanggal) $\%$

\# mutate (new_cases = c (cases [1], $\operatorname{diff}($ cases ) ) ) $\%$ \%

mutate (new cases smooth = round ( smoother: : smth (Penambahan Harian Kasus Terkonf, window $=7$, tai $\bar{S}=$ TRUE)

$$
\text { )) } \frac{\circ}{0}
$$

select(Provinsi, Tanggal,

Penambahan_Harian_Kasus_Terkonf, new_cases_smooth) ${ }^{-}$\}

\section{Filter Propinsi}

state selected <- "Sulawesi Selatan" covid_cases 응

filter (Provinsi $==$ state_selected) $\frac{\circ}{0}$

display random()

$$
\text { smooth_new_cases () } \frac{\circ}{0}
$$

\section{Hasil}

Tabel 1. Penambahan Kasus Karian Terkonfirmasi dan Pemulusannya

\begin{tabular}{l|c|c|c}
\hline Provinsi & Tanggal & PHKT* $^{*}$ & $\begin{array}{c}\text { PHKT } \\
\text { smooth }\end{array}$ \\
\hline $\begin{array}{l}\text { Sulawesi } \\
\text { Selatan }\end{array}$ & $2020-05-24$ & 32 & 40 \\
\hline
\end{tabular}

Jurnal Matematika dan Statistika serta Aplikasinya Vol. 8 No. 1 Ed. Jan - Juni 2020 


\begin{tabular}{l|c|c|c}
\hline \multicolumn{1}{c|}{ Provinsi } & Tanggal & PHKT* $^{*}$ & $\begin{array}{c}\text { PHKT } \\
\text { smooth }\end{array}$ \\
\hline $\begin{array}{l}\text { Sulawesi } \\
\text { Selatan }\end{array}$ & $2020-03-05$ & 0 & 0 \\
$\begin{array}{l}\text { Sulawesi } \\
\text { Selatan }\end{array}$ & $2020-04-03$ & 16 & 7 \\
$\begin{array}{l}\text { Sulawesi } \\
\text { Selatan }\end{array}$ & $2020-05-02$ & 30 & 31 \\
$\begin{array}{l}\text { Sulawesi } \\
\text { Selatan }\end{array}$ & $2020-04-27$ & 0 & 9 \\
$\begin{array}{l}\text { Sulawesi } \\
\text { Selatan }\end{array}$ & $2020-05-06$ & 25 & 23 \\
\hline
\end{tabular}

* Penambahan Harian Kasus Terkonfirmasi

\section{Grafik Kasus Baru Terkonfirmasi per Hari Propinsi Sulawesi Selatan}

plot new cases <- function(cases) \{ cases $\bar{\circ}>\overline{0}$ ggplot (aes ( $\mathrm{x}=$ Tanggal, $\mathrm{y}=$ Penambahan Harian Kasus Terkonf)) + geom_line('inetype $=$ 'dotted', color $=$ 'gray40') +

geom_line (aes (y = new_cases_smooth), color $=$ "\#14243e") + '̄abs (title =

"Kasus Baru per Hari",

subtitle = unique (cases\$Provinsi), $\mathrm{x}=$ NULL, $\mathrm{y}=\mathrm{NULL}$

) \}

covid_cases $\frac{0}{0}$

filter (Provinsi == state_selected) $\%$ \% smooth_new_cases () 응

plot_new_cases ()

Kasus Baru per Hari

Sulawesi Selatan

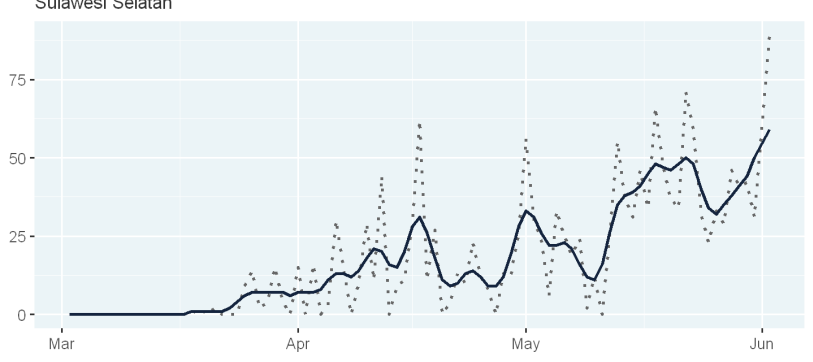

compute_likelihood <- function(cases) \{ likelihōod $<-$ cases 응

filter (new cases smooth > 0) 응

mutate ( $r_{-} \bar{t}=$ list (r_t_range), lambda

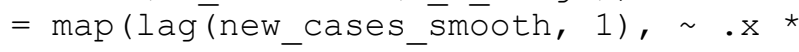

$\exp \left(\right.$ GAMMA * $\left(\bar{r} \_t\right.$ rañge -1$\left.\left.)\right)\right)$,

likelihood_r_t ${ }^{-}=$

map2 (new_casés_smooth, lambda, dpois, $\log =\operatorname{TR} \bar{U} E))$ 긍

slice $(-1) \div>$ select $\left(-1\right.$ ambda) $\frac{\circ}{0}>\circ$

unnest (c (likelihood_r_t, r_t))

covid_cases $\%$ ofilter(Provinsi ==

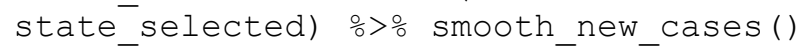

그을

display_rañdom()
Tabel 2. Nilai Estimasi Likelihood

\begin{tabular}{l|l|c|r|r|r}
\hline Provinsi & Tanggal & PHKT & $\begin{array}{r}\text { PHKT } \\
\text { smo } \\
\text { oth }\end{array}$ & $\mathbf{r}_{\mathbf{r}} \mathbf{t}$ & $\begin{array}{r}\text { likelihood_r } \\
\mathbf{t}\end{array}$ \\
\hline Sulawesi & $2020-04-$ & 0 & 16 & 10.47 & -158.273788 \\
Selatan & 13 & & & & \\
Sulawesi & $2020-06-$ & 89 & 59 & 11.74 & -528.219541 \\
Selatan & 02 & & 11 & 8.43 & -46.628205 \\
Sulawesi & $2020-05-$ & 12 & 11 & & \\
Selatan & 10 & & 13 & 9.10 & -48.391746 \\
Sulawesi & $2020-04-$ & 30 & 13 & \\
Selatan & 06 & & 10 & 11.78 & -99.431836 \\
Sulawesi & $2020-04-$ & 13 & 10 & & \\
Selatan & 22 & & 59 & 2.76 & -5.399832 \\
Sulawesi & $2020-06-$ & 89 & 59 & \\
Selatan & 02 & &
\end{tabular}

* Penambahan Harian Kasus Terkonfirmasi

\section{Menghitung Posterior}

compute_posterior <-

function (likelihood) \{likelihood 응 arrange (Tanggal) \%>group_by (r_t) $\%>$ mutate (posterior $=\exp ($

zoo: :rollapplyr (likelihood_r_t, 7, sum, partial = TRUE))) $\%>\circ^{-}$

group_by (Tanggal) \%>mutate (posterior = posterior / sum(posterior, na.rm = TRUE)) \%>。

\# Tidak Menghitungkan Nilai NA

mutate (posterior $=$

ifelse (is.nan (posterior), 0 , posterior)) 응 ungroup () 응

select (-likelihood_r_t)

covid_cases $\frac{\circ}{\circ}$

filte $\bar{r}$ (Provinsi $==$ state selected) $\frac{\circ}{0}$ \% smooth_new_cases () \% compute_̄ikelihood() $\frac{\circ}{0}>\frac{\circ}{\circ}$ compute_posterior () $\frac{\circ}{0}>$ display_random()

Tabel 3. Posterion dari Nilai $R_{t}$

\begin{tabular}{l|l|r|r|r|r}
\hline Provinsi & Tanggal & $\begin{array}{r}\text { PHK } \\
\text { T }\end{array}$ & mooth & r_t & $\begin{array}{r}\text { poste } \\
\text { rior }\end{array}$ \\
\hline Sulawesi & $2020-04-$ & 10 & 14 & 5.16 & 0 \\
Selatan & 09 & & & & \\
Sulawesi & $2020-05-$ & 33 & 32 & 6.98 & 0 \\
Selatan & 26 & & & 6.48 & 0 \\
Sulawesi & $2020-03-$ & 4 & 7 & \\
Selatan & 30 & & & \\
Sulawesi & $2020-04-$ & 0 & 8 & 4.54 & 0 \\
Selatan & 04 & & & & \\
Sulawesi & $2020-04-$ & 9 & 15 & 11.92 & 0 \\
Selatan & 14 & & & & \\
Sulawesi & $2020-04-$ & 10 & 14 & 5.45 & 0 \\
Selatan & 09 & & &
\end{tabular}

* Penambahan Harian Kasus Terkonfirmasi 


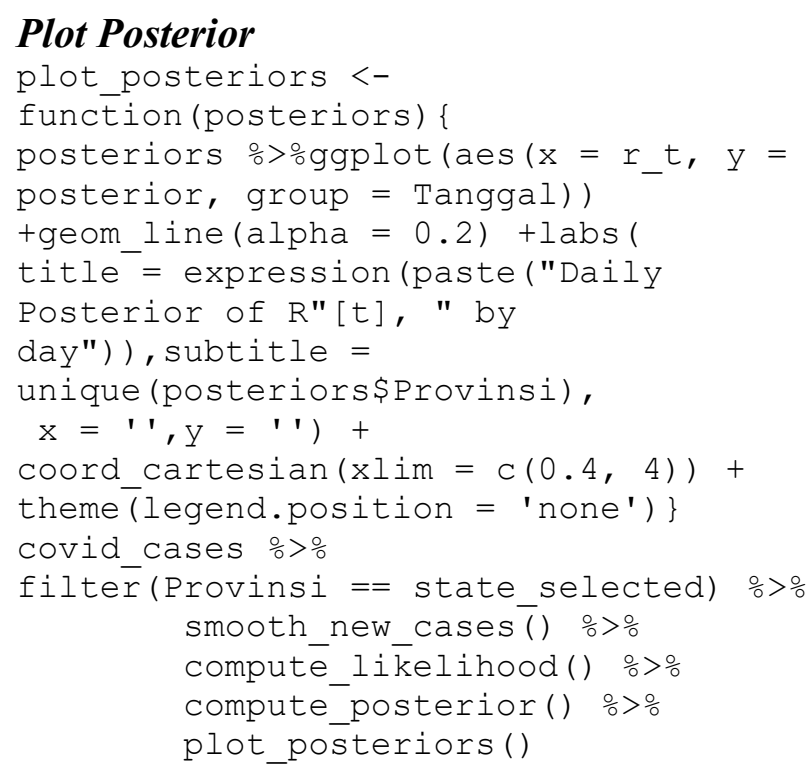

Gambar 1. Grafik Posterior Harian dari $\mathrm{R}_{\mathrm{t}}$

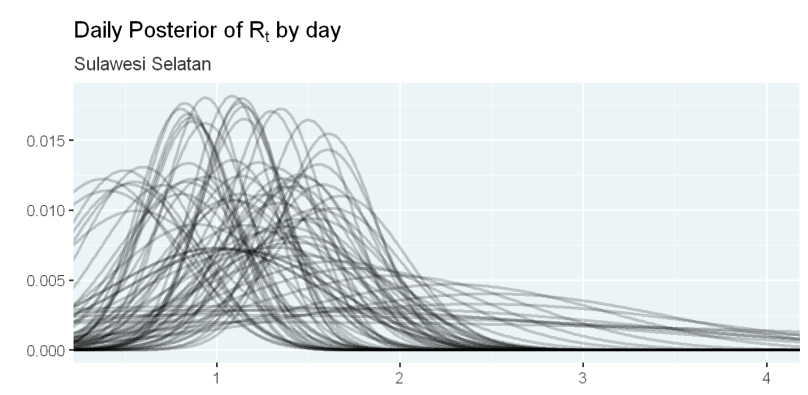

Estimasi Real Time $\left(R_{t}\right)$ interval 95\%

\# Estimate R t untuk interval 95\% estimate_rt $\overline{<}-$ function(posteriors) \{ posteriors \% \%group_by (Provinsi, Tanggal) $\frac{\circ}{\circ}$ summarize (r_t_simulated $=$ list (sample (r t range, $\overline{1} 0 \overline{0} 00$, replace

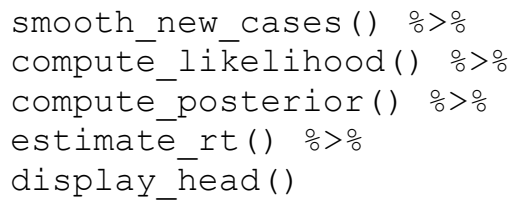

Gambar 2. Nilai Lo dan Hi Bandwidth dari nilai $\mathrm{R}_{\mathrm{t}}$ yang paling mungkin

\begin{tabular}{c|c|c|c|c}
\hline Provinsi & Tanggal & $\begin{array}{c}\text { r_t_mo } \\
\text { st_likel } \\
\mathbf{y}\end{array}$ & $\mathbf{r}$ _t_lo & $\mathbf{r}$ _t_hi \\
\hline Sulawesi Selatan & $2020-03-19$ & 1.00 & 0.00 & 6.32 \\
Sulawesi Selatan & $2020-03-20$ & 1.00 & 0.00 & 5.03 \\
Sulawesi Selatan & $2020-03-21$ & 1.00 & 0.00 & 4.36 \\
Sulawesi Selatan & $2020-03-22$ & 1.00 & 0.00 & 3.97 \\
Sulawesi Selatan & $2020-03-23$ & 1.73 & 0.00 & 4.13 \\
Sulawesi Selatan & $2020-03-24$ & 2.43 & 0.15 & 4.39 \\
\hline
\end{tabular}

\section{Grafik Estimasi Real Time $\left(R_{t}\right)$ Propinsi Sulawesi Selatan}

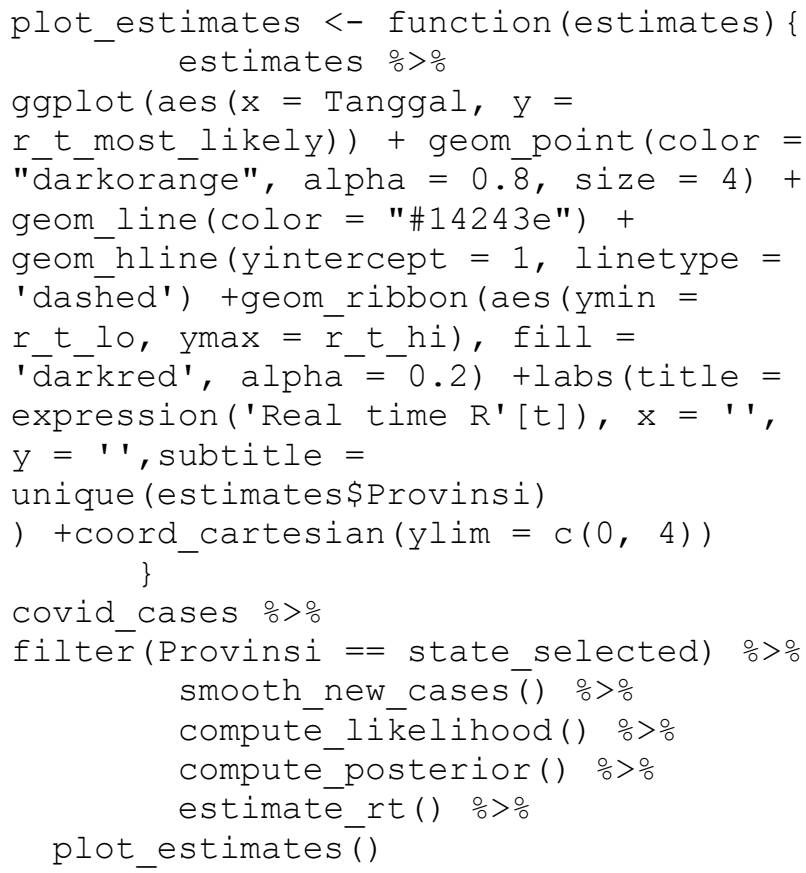

Gambar 3. Grafik Hasil Estimasi Real Time Propinsi Sulawesi Selatan

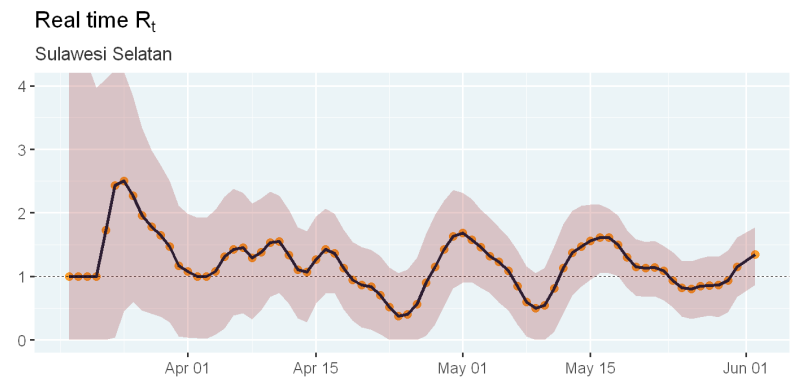

\section{Gambaran Umum Estimasi Semua Propinsi di Indonesia}

estimates all<- covid cases $\%>$

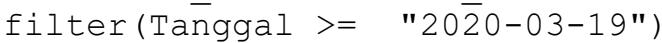
\% $>$ group_by (Provinsi) \% > \# Abaikan propinsi dengan terpapar kurang dari 50 


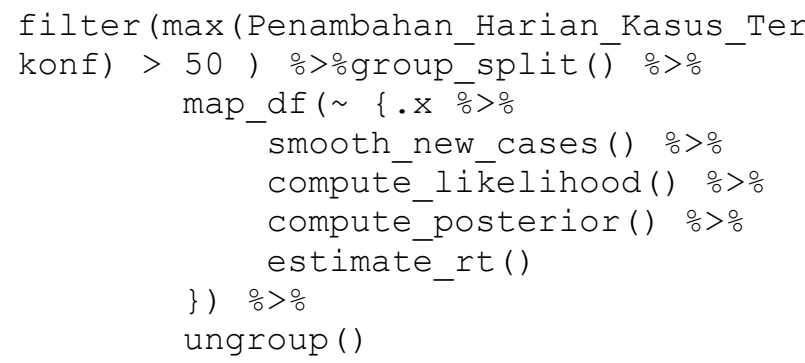

Tabel 4. Nilai Lo dan Ho Real Time untuk Propinsi dengan Kejadia diatas 50 PHKT

\begin{tabular}{|c|c|c|c|c|}
\hline Provinsi & Tanggal & $\begin{array}{r}r_{\text {st_tikel_mo }} \\
y\end{array}$ & -t_lo & r_t_hi \\
\hline $\begin{array}{l}\text { Nusa Tenggara } \\
\text { Barat }\end{array}$ & $\begin{array}{l}2020-04- \\
04\end{array}$ & 1.00 & 0.00 & 3.34 \\
\hline $\begin{array}{l}\text { Kalimantan } \\
\text { Timur }\end{array}$ & $\begin{array}{l}2020-05- \\
25\end{array}$ & 2.39 & 0.97 & 3.67 \\
\hline DKI Jakarta & $\begin{array}{l}2020-04- \\
20\end{array}$ & 0.91 & 0.65 & 1.16 \\
\hline DKI Jakarta & $\begin{array}{l}2020-04- \\
23\end{array}$ & 0.83 & 0.57 & 1.10 \\
\hline $\begin{array}{l}\text { Sulawesi } \\
\text { Tenggara }\end{array}$ & $\begin{array}{l}2020-06- \\
02\end{array}$ & 0.86 & 0.00 & 2.08 \\
\hline $\begin{array}{l}\text { Sumatera } \\
\text { Selatan }\end{array}$ & $\begin{array}{l}2020-04- \\
07\end{array}$ & 0.65 & 0.00 & 2.57 \\
\hline
\end{tabular}

Grafik gambaran Umum Semua Propinsi

\# Merubaha tinggi dan lebar area

grafik

options (repr.plot.height $=10$,

repr.plot.width $=20$ )

estimates_all 으이estimates() +

facet_wrap ( Provinsi, ncol = 4) + labs (subtitle = " ")

\# Pengaturan ulang

options (repr.plot.height $=12$,

repr.plot.width $=8$ )

Gambar 4. Grafik Estimasi Real Time Propinsi dengan Kejadian PHKT lebih dari 50 Kejadian

Real time $R$

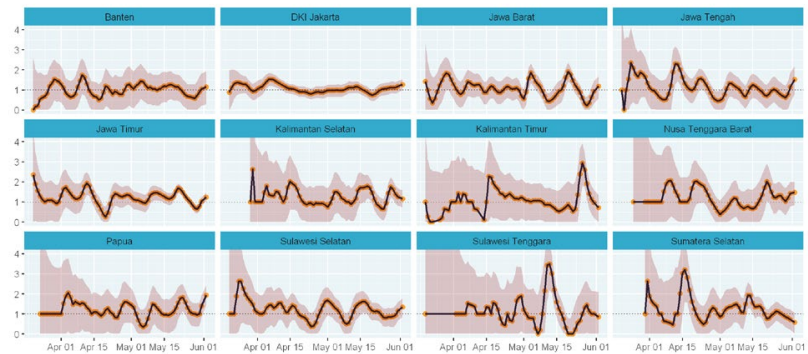

\section{DISKUSI}

Dari hasil estimasi memperlihat kejadian harian yang fluktuatif, namun dari akhir periode dari data yang digunakan nampak kejadian cenderung naik.

Estimasi dengan menggunakan pendekatan lain dimungkinkan untuk digunakan yang hasilnya dapat dibandingkan dari setiap pendekatan tersebut.

\section{DAFTAR PUSTAKA}

[1] Bettencourt LMA, Ribeiro RM (2008) Real Time Bayesian Estimation of the Epidemic Potential of Emerging Infectious Diseases. PLoS ONE 3(5): e2185. https://doi.org/10.1371/journal.pone.00021 85

[2] Mwangi TW, Fegan G, Williams TN, Kinyanjui SM, Snow RW, Marsh K (2008) Evidence for Over-Dispersion in the Distribution of Clinical Malaria Episodes in Children. PLoS ONE 3(5): e2196. https://doi.org/10.1371/journal.pone.0002196

[3] Haign John, (2002) Probability Models. Springer. London.

[4] David J. Olive, (2014). Statistical Teory and Inferences. Springer. London.

[5] Murray Logan,(2010) Biostatistical Design and Analysis Using R, John Wiley \& Sons, Inc. New York.

[6] Gergely Daróczi ,(2015)Mastering Data Analysis with R. Packt Publishing. Birmingham, UK.

[7] Data Covid-19 Indonesia. https://prod-hubindexer.s3.amazonaws.com/files/685be21cd 0034247b5ceeac996d947fe/0/full/4326/685 be21cd0034247b5ceeac996d947fe_0_full 4326.csv 